М. А. Андрейчин, О. Л. Івахів, Н. Ю. Вишневська, В. О. Качор, І. С. Іщук, Я. І. Йосик, Н. А. Васильєва, В. С. Копча, Н. А. Ничик, Н. Г. Завіднюк ДВНЗ “Тернопільський державний медичний університет імені І. Я. Горбачевського МОЗ України”

\title{
ПРАКТИЧНІ НАВИЧКИ ДЛЯ СТУДЕНТІВ МЕДИЧНОГО ФАКУЛЬТЕТУ НА КАФЕДРІ ІНФЕКЦІЙНИХ ХВОРОБ 3 ЕПІДЕМІОЛОГІЄЮ: НОВІ ПІДХОДИ ТА ОПТИМІЗАЦІ НАВЧАННЯ
}

\author{
M. A. Andreychyn, O. L. Ivakhiv, N. Yu. Vyshnevska, V. O. Kachor, I. S. Ischuk, \\ Ia. I. Iosyk, N. A. Vasylyeva, V. S. Kopcha, N. A. Nychyk, N. H. Zavidnyuk \\ I. Horbachevsky Ternopil State Medical University

\section{PRACTICAL SKILLS OF MEDICAL FACULTY STUDENTS AT THE APPROACHES AND OPTIMIZATION OF TEACHING} \\ INFECTIOUS DISEASES AND EPIDEMIOLOGY DEPARTMENT: NEW
}

\begin{abstract}
Мета роботи - поліпшити якість засвоєння нових практичних навичок студентами на кафедрі інфекційних хвороб завдяки вдосконаленню методів викладання.

Основна частина. У статті наведено підходи викладачів кафедри інфекційних хвороб до навчання практичних навичок студентів з наданням переваги сучасним методам діагностики інфекційної патології та використанню новітніх досягнень медичної науки.

Висвітлено проблемні питання підготовки студентів з інфекційних хвороб у вищих медичних навчальних закладах. Наводиться досвід впровадження в навчальний процес нових методик із використанням як теоретичних, так і практичних методів для формування практичних навичок у майбутніх лікарів з дисципліни “Інфекційні хвороби”.

Висновки. Удосконалення засвоєння практичних навичок у клініці інфекційних хвороб, як і на інших клінічних кафедрах, - це складний і тривалий процес. Необхідно більше уваги приділяти оволодінню студентами не тільки традиційними, а й новітніми методами діагностики інфекційних хвороб і лікування хворих, використовуючи й розробки колективу кафедри.

Ключові слова: студенти; інфекційні хвороби; практичні навички; нові методи діагностики; сучасне лікування хворих.

The aim of the work - to improve the quality of new practical skills by students at the Department of Infectious Diseases through the improvement of teaching methods.

The main body. The article presents the approaches of teachers of the Department of Infectious Diseases to the teaching of practical skills of students with the advantages of modern methods of diagnosing infectious diseases and the use of the latest advances in medical science. The problematic questions of students' training in infectious diseases in higher educational institutions are highlighted. The experience of new methods' introduction in the educational process using both theoretical and practical methods for the formation of practical skills for future physicians in the discipline of Infectious Diseases is presented.

Conclusions. Improving the learning of practical skills in the clinic of infectious diseases, as well as in other clinical departments is a complex and lengthy process. It is necessary to pay more attention to mastering students not only traditional, but also the newest methods of infectious diseases diagnosing and treatment of patients, using the impact of the department' staff.
\end{abstract}

Key words: students; infectious diseases; practical skills; new methods of diagnostics; modern treatment of patients.

Вступ. Упродовж останніх років суттєво змінюються та удосконалюються технології навчального процесу і все ширше впроваджуються нові технічні засоби викладання дисциплін та інформаційні комп’ютерні технології [1]. Однак найважливішим залишається навчити майбутнього лікаря спілкування з пацієнтом: знайти контакт з ним і завоюва-

() М. А. Андрейчин, О. Л. Івахів, Н. Ю. Вишневська та ін. ти довіру; зібрати скарги, анамнез життя і хвороби, алергологічний та епідеміологічний анамнези, а також провести ретельний лікарський огляд хворого. На підставі отриманих даних студент повинен сформулювати попередній діагноз, призначити відповідні обстеження, а далі - й лікування. Тому пошук нових підходів в оптимізації засвоєння практичних навичок студентом з формуванням системи 
їх застосування, що складає основу його майбутньої професійної майстерності, є особливо актуальним у період реформування медичної галузі [2, 3].

Мета роботи - поліпшити якість засвоєння нових практичних навичок студентами на кафедрі інфекційних хвороб завдяки вдосконаленню методів викладання.

Основна частина. Діагностика того чи іншого інфекційного патологічного процесу починається 3 першого етапу - спілкування з пацієнтом. Майбутній лікар повинен не тільки знати, але й вміти вислухати й почути пацієнта [4]. У цьому студенту повинен допомогти викладач, який з першого практичного заняття у клініці інфекційних хвороб привчає його до комунікативних навичок, вміння знайти індивідуальний підхід до кожного пацієнта зокрема, з урахуванням його віку, статі, інтелектуального розвитку тощо. Студент повинен враховувати й те, що для більшості пацієнтів сама думка про інфекційну недугу спричинює пригніченість, переживання щодо можливості зараження родичів і друзів, тому потрібно проводити певну роз'яснювальну і просвітницьку роботу.

Основним у клінічній практиці майбутнього лікаря $\epsilon$ оволодіння сучасними загальноклінічними методами і технікою клінічного обстеження пацієнта, що дозволяє отримати важливу інформацію про патологічний стан, і розвивати клінічне мислення. Це дасть змогу майбутньому фахівцю своєчасно запідозрити хворобу в пацієнта, у тому числі й інфекційну, у повному обсязі призначити всебічне обстеження та оптимальне високоефективне лікування, а також розробити і здійснити комплекс протиепідемічних заходів, спрямованих на запобігання розповсюдженню інфекційної недуги у суспільстві.

Організація засвоєння практичних навичок потребує значної підготовчої роботи. Практичні навички краще засвоюються лише тоді, коли вони здобуті шляхом самостійної роботи з хворим. До кожної практичної навички на кафедрі розробляється приблизний алгоритм дій студента при спілкуванні 3 хворим із провідним патологічним синдромом (діарейний, респіраторний, жовтяниця тощо), а також широко використовуються створені викладачами кафедри віртуальні програми та відеофільми.

Перед початком кожного навчального року на методичному засіданні колектив кафедри розглядає сучасні методи обстеження інфекційних хворих 3 урахуванням новітніх досягнень медичної науки у цілому й інфектології зокрема, можливості втілення їх у навчальний процес, розробляє для студентів алгоритм виконання навичок і поповнює кафедральний “банк” обов’ язкових практичних навичок. Так, в останні роки на кафедрі для визначення ступеня фіброзу у хворих на вірусні гепатити поряд зі старими методами (наприклад, розрахунок індексу FIB-4) навчають студентів трактування результатів нових неінвазивних методів - за даними фібротесту, фіброметера чи еластографії печінки.

Відомим і досить інформативним методом діагностики інфекційних хвороб залишається дистанційна термографія (реєстрація інфрачервоного випромінювання тіла людини). Метод абсолютно нешкідливий і необтяжливий для хворого і медичного персоналу. Колектив кафедри тривалий час розробляє термосеміотику розповсюджених інфекційних хвороб, має багато власних розробок, захищених патентами України. Нещодавно університет придбав для кафедри сучасний портативний, високочутливий термограф. На заняттях викладачі навчають студентів проведення термографії і оцінки термограм хворих на грип та інших ГРВI, вірусні гепатити, лептоспіроз, харчову токсикоінфекцію, шигельоз, черевний тиф, оперізувальний герпес, бешиху, гарячку нез'ясованої етіології. Наводяться приклади зростання інформативності та достовірності термодіагностики, якщо водночас застосувати інші методи інструментального дослідження - ультразвуковий, рентгенологічний, ендоскопічний тощо.

Працівники кафедри беруть активну участь у виконанні комплексної науково-дослідної роботи університету "Вивчення епідеміології, патогенезу і клініки лайм-бореліозу в ендемічних регіонах України, в тому числі в Тернопільській області, та вдосконалення його діагностики, терапії, реабілітаційних заходів і профілактики”, яка виконується частково за кошти з Державного бюджету України. На практичному занятті студентів навчають тактики при виявленні кліща на тілі людини, методики його видалення, комплексу профілактичних заходів щодо лайм-бореліозу. Для діагностики цієї трансмісивної інфекції пропонується високоінформативна двохетапна схема обстеження пацієнта: спочатку використовують високочутливий імуноферментний аналіз (ІФА), а осіб з позитивними результатами обстежують ще й високоспецифічним методом імуноблоту для остаточного підтвердження діагнозу та прогнозу перебігу захворювання в конкретного пацієнта. На практичному занятті студентів навчають правильно трактувати результати зазначених обстежень.

Значну увагу викладачі приділяють навчанню студентів високоефективних методів лікування хворих, розроблених на кафедрі, зокрема опромінення слизової оболонки носа, піднебінних мигдаликів, 
ділянок запалення, а також біологічно активних точок низькоінтенсивним лазерним світлом при грипі та інших ГРВI, гострому і хронічному тонзиліті, фарингіті, синуситах, бешисі, еризипелоїді тощо; обпилення верхніх дихальних шляхів препаратами інтерферону альфа.

Самостійна практична робота студентів 6-го курсу у приймальному відділенні інфекційного стаціонару дає їм можливість ознайомитися з медичною документацією, протоколами надання медичної допомоги хворим, поглибити і закріпити вміння й навички у наданні допомоги хворим на етапі госпіталізації. Під керівництвом викладача студенти самостійно оглядають хворого, заповнюють Карту стаціонарного хворого, формулюють попередній діагноз, визначають план обстеження і лікування.

Кращому засвоюванню практичних навичок $з$ інфекційних хвороб сприяють й вечірні чергування студентів 6-го курсу в клініці інфекційних хвороб, під час яких вони під наглядом чергового лікаря приймають хворих на лікування, оглядають пацієнтів з тяжким перебігом недуги, призначають відповідні ліки. Наступного ранку чергові звітують на загальноклінічній нараді, де проводиться ре-

\section{Список літератури}

1. Волосовець О. П. Питання якості освіти в контексті впровадження засад Болонської декларації у вищій медичній школі / О. П. Волосовець // Медична освіта. 2005. - № 2. - С. 12-16.

2. Івченко В. К. Про деякі проблеми практичної підготовки фахівців / В. К. Івченко, П. С. Меженський, О. I. Швець // Проблеми медичної науки та освіти. 2001. - № 3. - С. 32-33.

3. Сучасні методики навчання й оцінювання знань студентів у клініці інфекційних хвороб / Н. Ю. Вишнев-

\section{References}

1. Volosovets, O.P. (2005). Pytannia yakosti osvity v konteksti vprovadzhennia zasad Bolonskoi deklaratsii u vyshchii medychnii shkoli [Issues of quality of education in the context of implementation of the principles of the Bologna Declaration in the Higher Medical School]. Medychna osvita - Medical Education, 2, 12-16 [in Ukrainian].

2. Ivchenko, V.K., Mezhenskyi, P.S., \& Shvets, O.I. (2001). Pro deiaki problemy praktychnoi pidhotovky fakhivtsiv [About some problems of practical training of specialists]. Problemy medychnoi nauky ta osvity - Problems of Medical Science and Education, 3, 32-33 [in Ukrainian].

3. Vyshnevska, N.Iu., Ivakhiv, O.L., Vasylieva, N.A., \& Ishchuk, I.S. (2017). Suchasni metodyky navchannia y тельний розбір їх роботи. Систематично студенти беруть участь у клінічних конференціях.

Участь у програмі “Студент - майбутній фахівець” дає можливість студентам виробляти навички творчого підходу для вирішення конкретних завдань практичної охорони здоров'я, розширити науковий і практичний світогляд майбутнього лікаря-фахівця, повніше і глибше засвоїти матеріал.

Кінцева оцінка якості засвоєння практичних навичок студентами 5-го курсу медичного факультету здійснюється під час об’єктивно-структурованого клінічного іспиту.

Висновки. Удосконалення засвоєння практичних навичок у клініці інфекційних хвороб, як і на інших клінічних кафедрах, - це складний і тривалий процес. Необхідно більше уваги приділяти оволодінню студентами не тільки традиційними, а й новітніми методами діагностики інфекційних хвороб і лікування хворих, використовуючи й розробки колективу кафедри.

У перспективі слід продовжувати навчати студентів методів обстеження інфекційних хворих i їх лікування, щороку оновлюючи базу практичних навичок, використовуючи новітні досягнення медичної науки.

ська, О. Л. Івахів, Н. А. Васильєва, І. С. Іщук // Медична освіта. - 2017. - № 1. - С. 8-13.

4. Голубовська О. А. Проблема формування практичних навичок у майбутнього лікаря при викладанні інфекційних хвороб / О. А. Голубовська, А. В. Шкурба, K. I. Чепілко // Діагностика і терапія інфекційних хвороб на різних рівнях надання медичної допомоги : матеріали Всеукр. наук.-практ. конф. і пленуму ГО ВАІ (2930.09.16, Вінниця). - Тернопіль : ТДМУ, 2016. - С. 45-46.

otsiniuvannia znan studentiv u klinitsi infektsiinykh khvorob [Modern methods of teaching and evaluating students' knowledge in the clinic of infectious diseases]. Medychna osvita - Medical Education, 1, 8-13 [in Ukrainian].

4. Holubovska, O.A., Shkurba, A.V., \& Chepilko, K.I. (2016). Problema formuvannia praktychnykh navychok u maibutnoho likaria pry vykladanni infektsiinykh khvorob [The problem of forming practical skills for a future doctor in the teaching of infectious diseases]. Diahnostyka $i$ terapiia infektsiinykh khvorob na riznykh rivniakh nadannia medychnoi dopomohy: Mater. Vseukr. nauk.-prakt. konf. i plenumu IDDU (29-30.09.2016, Vinnytsia). Ternopil: TDMU, Ukrmedknyha [in Ukrainian]. 